\title{
FACTORS MOTIVATING WOMEN TO STUDY TECHNOLOGY: A QUANTITATIVE SURVEY AMONG YOUNG WOMEN IN NORWAY
}

\author{
Hilde G. Corneliussen, Gilda Seddighi, Anna Maria Urbaniak-Brekke and Morten Simonsen \\ Western Norway Research Institute, Norway
}

\begin{abstract}
Women's underrepresentation in fields of information and communication technology (ICT) appears as a paradox in the context of Norway, a country that scores high on international gender equality indicators. Earlier research has argued that women's underrepresentation in ICT education might be a result of their lack of interest in ICT. In this paper we ask what motivates young women in Norway to enter technology studies. The analysis is based on a quantitative survey with 689 young women responding to questions about what had made them choose technology in high school or at university level. The results show that leading factors motivating the women are job opportunities, high salary and using technology for solving challenges. Interestingly, factors that are associated with boys' and men's interest in ICT such as computer games and leisure activities, are marginal as motivation for the women. The study thus confirms that young women are highly interested in fields of technology, however, their interests differ from what is often associated with young men. Based on the findings we suggest that measures recognising a wider image of technology are needed for motivating women to enter fields of technology.
\end{abstract}

\section{KEYWORDS}

Technology Studies, ICT Education, Motivational Factors, Young Women, Quantitative Data

\section{INTRODUCTION}

What motivates girls and women to study technology? This is an important question in today's society where technology has become ubiquitous across spheres and sectors. Digitalization has increased the need for technological experts and skills, suggesting a need for recruiting widely among young people, including women (Barbieri et al., 2020). However, women's underrepresentation in technology education and work has been persistent in many countries across the Western world. Currently, about $18 \%$ of information and communication technology (ICT) specialists in EU are women (EUROSTAT, 2019). In this paper we explore what motivates young women in Norway to study technology. Even though Norway scores high on international gender equality indicators, it has a strongly gender-segregated education and labour market. This is among other things visible in the fact that girls make up only one in four applicants to higher technology education in Norway (Samordna opptak, 2020).

Studies show that girls who are facing educational choices assume that boys have a higher interest in ICT than girls, and therefore also assume that boys are more skilled than girls in ICT subjects (Corneliussen, 2021). Although it has been suggested that women's lower participation in technology subjects is a result of lower career ambitious than men (Stoet \& Geary, 2018), this is not supported by women's high participation in education and the labour force in Norway (Statistics Norway, 2018).

Both Norwegian and international research show that gender stereotypes identifying technology with boys and men make it particularly challenging for girls and women to establish professional self-confidence in technology and science (Cheryan et al., 2009; Jethwani et al., 2016; Margolis \& Fisher, 2002; OECD, 2016). Such stereotypes also make it difficult for girls to identify female role models in technology professions (Corneliussen et al., 2019). While insight into higher technology education is a scarce commodity among both girls and boys (Grover et al., 2014), lack of such insight is more problematic for girls than for boys. Studies of girls' paths to technology education show that girls more than boys need support in order to make non-traditional educational choices (Corneliussen, 2021). This suggests that family and school are important supporters for girls' non-traditional educational choices (Eccles, 2015; Wang et al., 2015). 
However, both parents and teachers have low expectations towards girls' interest in technology subjects (The Think Tank DEA, 2019), and girls are to a lesser degree than boys encouraged to engage in technology-related activities, both in education and leisure time (Corneliussen \& Prøitz, 2016; Microsoft Corporation, 2017). Drawing from this literature, we explore what motivates young women to consider technology education as a relevant choice. Below we describe the quantitative method and the data gathered, before we present the analysis of how the women responded to the potential motivational factors we tested in this study.

\section{METHOD}

This paper is based on data gathered through a quantitative, online survey, with the title: "What motivates young women to choose technical vocational subjects, science subjects and technology subjects?" The questionnaire was distributed among young women to map a number of motivational factors. Attitudes were measured on a Likert scale with 5 values (e.g., strongly disagree, disagree, neutral, agree, strongly agree).

The survey was disseminated via random schools from all over Norway and through a majority of higher education institutions and vocational colleges. A total of 689 respondents completed the survey. Out of these, $61 \%$ were university and college students, $22 \%$ were students at upper secondary schools, and $9 \%$ at technical vocational schools. The survey includes young women from all parts of the country and respondents are distributed by city and village approximately in accordance with the general distribution of inhabitants in Norway. $7.7 \%$ of respondents were born in other countries than Norway, while the number of inhabitants with an immigrant background in Norway today is nearly $15 \%$.

It is important to mention that in the question about factors influencing their motivation to study technology, respondents had the opportunity to choose more than one answer, and that is why the total number of answers (responses) is higher than the number of respondents. In order to avoid misunderstandings between number of respondents and number of responses, we present the results below in percentage (\%).

\section{FACTORS THAT INFLUENCE GIRLS' INTEREST IN TECHNOLOGY}

We asked the women about a number of potential motivational factors identified in previous research, including motivational factors often associated with boys' "advantages" in technology (Corneliussen, 2021). This includes importance of support from family and school (Eccles, 2015; Ikonen et al., 2018), attitudes to technology originating in leisure activities and experiences from school (Master et al., 2017), and expectations for future profession and career (Vainionpää et al., 2019). The figure below (figure 1) provides an overview of how the girls responded "agree" (including "strongly agree"), "neutral" or "disagree" (including "strongly disagree") on the question of whether these factors have influenced them to choose or considering choosing science or technology subjects at high school or at university. In this part of the paper, we present the factors that prove to be most important for the respondents.

\subsection{Working Life}

As figure 1 shows, ambitions associated with working life dominate among the motivating factors for choosing science and technology subjects among the women, and all these factors have received more than $50 \%$ support. "Exciting job opportunities in technology professions" reigns supremely with over 93\% agreement. More than $80 \%$ of the women agree that "job opportunities", the importance of "technology knowledge", and opportunities for a "good salary" are important motivating factors. In contrast to an often-repeated scepticism towards women's interest in technology, more than 3 out of 4 women in our study want to work with technology. More than $70 \%$ of the women are motivated by technology as a means of working practically and more than $80 \%$ are encouraged by using technology for solving societal challenges. A lower proportion, but still more than half, is motivated by the fact that "girls are wanted in technology professions", suggesting that a majority of the young women feel welcome in technology. About 3 in 4 applicants to health care are women in Norway (Samordna opptak, 2020). Therefore, we also wanted to learn whether the link between health care and technology was of interest for young women. Nearly 3 in 5 women agreed that "technology as important in the health sector" was motivating for choosing technology. 


\subsection{Schools and Education}

"Technology as an elective in upper secondary school" is the most important motivating factor associated with schools and education, with 53\% women agreeing that this has had the greatest impact on the choice of studying technology. On the other hand, only $26 \%$ agree that "technology as an elective in secondary school" has been important. This may reflect that the young women had not perceived technology at secondary school as very motivating, but it may also reflect that technology has not been a widespread elective at lower secondary levels in Norway.

Teachers' encouragement is the second most important motivating factor associated with schools, with $40 \%$ identifying this as important, with information received at an Education Fair (an annual event) (38\%), and information from supervisors, teachers, and others at school $(35.6 \%)$ following close behind. "Events that make girls familiar with technology" and "visits by technology companies" are among the factors that score the lowest with $25.5 \%$ and $24 \%$.

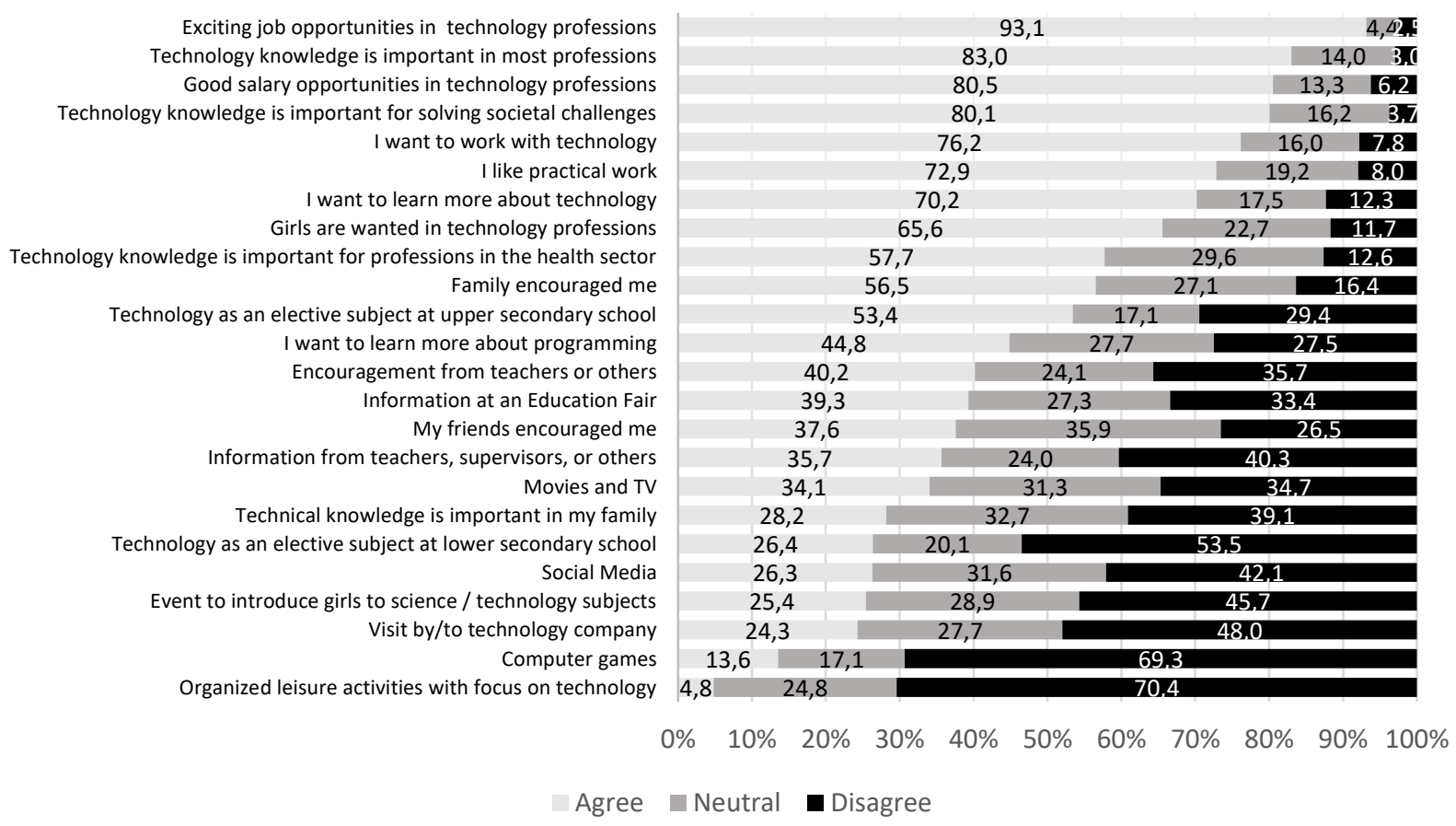

Figure 1. What has had the greatest impact on your choice of technical vocational subjects, science subjects, engineering, and technology subjects?

\subsection{Family, Friends, and Leisure Activities}

The family is important as a source of encouragement (56\%). This is relatively independent of the family's relationship to technology, since only $28 \%$ of the women agree that technology is important in their family. Social media plays a role as a motivating factor for about one in four women, while traditional media such as film and TV scores slightly higher. Encouragement from friends scores 19 percentage points lower than encouragement from family and suggests that family influences the choice of field of study more than friends.

Contrary to what is often expected in surveys of boys' study choices (DiSalvo \& Bruckman, 2009), we find that "computer games" (13.5\%) and "leisure activities with focus on technology" (5\%) are among the motivating factors that received the least support among the women. It is particularly interesting to note that some of the motivating factors that are most associated with boys and men (McKinsey \& Company and Pivotal Ventures, 2018) have the least significance for the women in our study. 


\section{DISCUSSION}

Gendered perceptions related to educations and professions influence young people who are in the process of choosing a career path. Gender stereotypes are shown to limit young people's "opportunities" - i.e., which professions and educations they can imagine themselves to enter (NOU, 2019: 19). For instance, subject areas related to ICT are often associated with boys' and men's interest in ICT such as gaming, and programming as a leisure time activity (McKinsey \& Company and Pivotal Ventures, 2018). The same types of activities got a low score by the women in our survey and are thus less important for motivating young women to enter technology programs. Many of the highest rated motivational factors by women rather emphasise the importance of technology and technology knowledge in a future career perspective. More specifically, using technology for solving societal challenges was identified as an important motivation by 4 out of 5 women. Thus, different from earlier research claiming that girls are less ambitious in technology education and career than boys (Stoet \& Geary, 2018), we find that the factors which have the greatest meaning for women considering studying technology are connected mainly to future career opportunities. Exciting jobs, good salary, and technology knowledge as important were the main motivational factors for our respondents.

Other studies show that parental support and encouragement is important for young people's educational choices, and especially for girls' and young women's choice to enter male dominated educational fields (Eccles, 2015; Think Tank DEA, 2019; Wang et al., 2015). Our study, however, supports earlier research finding that girls' and young women find less support and encouragement than boys and men from family and school for choosing technology. Our study shows that influence from family and school means less, and particularly at lower secondary school, few respondents felt that they had been motivated to think about choosing technology in their future education. Thus, we find that school, one of the main arenas for preparing students for future career ambitions, seem to play a minor role in motivating girls and young women for choosing technology. Furthermore, lower secondary school play a less important role for motivating young women than upper secondary school. This indicates that the young women have received support and encouragement for choosing technology late in the process of identifying the field of their future career.

\section{CONCLUSION}

To sum up, our survey documents that activities and interests that have been perceived as a door opener to ICT education for boys and men, in particular activities associated with leisurely relations to computers, have not had the same importance for young women. This should, however, not be misunderstood as women's lack of interest for technology, as the survey also documents young women's motivation to study technology. However, the most important motivational factors are associated with career prospects, solving societal challenges, and a desire to learn and to work with technology. The conclusion we draw from this study is thus that young women have high ambitions for choosing to study and work with technology, but also that they experience limited support from schools and family - arenas representing important influence on educational choices.

It has been suggested that measures are needed for supporting girls and young women to choose male dominated studies such as technology (Corneliussen, 2021; Margolis \& Fisher, 2002). The actions should, however, involve schools to a greater extent than the survey documents, and the involvement should be at an earlier stage than upper secondary school. Furthermore, the study suggests that presenting technology as vital for solving societal challenges makes technology more attractive for young women.

Rather than emphasising technology in the image of boys' and men's interests in technology as a leisure activity (Corneliussen \& Seddighi, 2020), the perspective of technology as important for solving societal challenges involves alternative images of technology, for instance associated with environmental issues. More importantly, a wider notion of what technology can be will also challenge gender stereotypes of who fits to work with technology. 


\section{ACKNOWLEDGMENT}

The project was assigned and funded by the Norwegian Directorate for Children, Youth, and Family Affairs.

\section{REFERENCES}

Barbieri, D., Caisl, J., Karu, M., Lanfredi, G., Mollard, B., Peciukonis, V., . . Salanauskaitè, L. (2020). Gender Equality Index 2020: Digitalisation and the future of work. Luxembourg: EIGE: European Institute for Gender Equality.

Cheryan, S., Plaut, V. C., Davies, P. G., \& Steele, C. M. (2009). Ambient Belonging: How Stereotypical Cues Impact Gender Participation in Computer Science. Journal of Personality and Social Psychology, 97(6), 1045-1060.

Corneliussen, H. G. (2021). Women empowering themselves to fit in ICT. In E. Lechman (Ed.), Technology and Women's Empowerment. London: Routledge.

Corneliussen, H. G., \& Prøitz, L. (2016). Kids Code in a rural village in Norway: could code clubs be a new arena for increasing girls' digital interest and competence? Information, Communication \& Society, 19(1), 95-110.

Corneliussen, H. G., \& Seddighi, G. (2020). Employers' Mixed Signals to Women in IT: Uncovering how Gender Equality Ideals are Challenged by Organizational Context. In P. Kommers \& G. C. Peng (Eds.), Proceedings for the International Conference ICT, Society, and Human Beings 2020 (41-48). IADIS: IADIS Press.

Corneliussen, H. G., Seddighi, G., \& Dralega, C. A. (2019). Women's Experience of Role Models in IT: Landmark women, substitutes, and supporters. In Ø. Helgesen, E. Nesset, G. Mustafa, P. Rice, \& R. Glavee-Geo (Eds.), Modeller: Fjordantologien 2019 (375-395). Oslo: Universitetsforlaget.

DiSalvo, B. J., \& Bruckman, A. (2009). Questioning video games' influence on CS interest Proceedings of the 4th International Conference on Foundations of Digital Games (272-278): ACM.

Eccles, J. S. (2015). Gendered Socialization of STEM Interests in the Family. Journal of Gender, Science and Technology, 7(2), 116-132. Retrieved from http://genderandset.open.ac.uk/index.php/genderandset/ article/view/419/692

EUROSTAT. (2019). ICT specialists in employment: statistics explained. https://ec.europa.eu/eurostat/statisticsexplained/index.php/ICT_specialists_in_employment [Accessed 10 May 2021].

Grover, S., Pea, R., \& Cooper, S. (2014). Remedying misperceptions of computer science among middle school students Proceedings of the 45th ACM technical symposium on Computer science education (343-348): ACM.

Ikonen, K., Leinonen, R., Asikainen, M. A., \& Hirvonen, P. E. (2018). The influence of parents, teachers, and friends on ninth graders' educational and career choices. 2018, 9(3), 316-338. Retrieved from http://genderandset.open.ac.uk/index.php/genderandset/article/view/526/876

Jethwani, M. M., Memon, N., Seo, W., \& Richer, A. (2016). “I Can Actually Be a Super Sleuth”: Promising Practices for Engaging Adolescent Girls in Cybersecurity Education. Journal of Educational Computing Research, 55(1), 3-25.

Margolis, J., \& Fisher, A. (2002). Unlocking the clubhouse. Women in computing. Cambridge, Mass.: MIT Press.

Master, A., Cheryan, S., Moscatelli, A., \& Meltzoff, A. N. (2017). Programming experience promotes higher STEM motivation among first-grade girls. Journal of Experimental Child Psychology, 160, 92-106.

McKinsey \& Company and Pivotal Ventures. (2018). Rebooting representation: Using CSR and philanthropy to close the gender gap in tech. https://www.rebootrepresentation.org/report-highlights/ [Accessed 10 May 2021].

Microsoft Corporation. (2017). Why Europe's Girls Aren't Studying STEM. https://bit.ly/2Q3Ba6q White paper, Microsoft Philanthropies [Accessed 10 May 2021].

NOU. (2019: 19). Jenterom, gutterom og mulighetsrom - Likestillingsutfordringer blant barn og unge. Oslo:KUD.

OECD. (2016). PISA 2015 results (Volume I). Excellence and equity in education. Paris: OECD Publishing.

Samordna opptak. (2020). The Norwegian Universities and Colleges Admission. https://www.samordnaopptak.no.

Statistics Norway. (2018). Women and men in Norway. Oslo: Statistics Norway.

Stoet, G., \& Geary, D. C. (2018). The Gender-Equality Paradox in Science, Technology, Engineering, and Mathematics Education. Psychological Science, 29(4), 581-593. doi:10.1177/0956797617741719

The Think Tank DEA. (2019). Putting the spotlight on STEM possibilities for youths in Denmark: Does gender play a role in developing youths' interest in STEM? https://bit.ly/3q6I0po [Accessed 16 June 2021].

Vainionpää, F., Kinnula, M. et al. (2019). Gendering and Segregation in Girls' Perceptions of IT as a Career Choice: A Nexus Analytic Inquiry. In A. Siarheyeva, C. Barry et al. (Eds.), Information Systems Development: Information Systems Beyond 2020 (ISD 2019 Proceedings) (1-12). Toulon, France: ISEN Yncréa Méditerranée.

Wang, J., Hong, H., Ravitz, J., \& Ivory, M. (2015). Gender differences in factors influencing pursuit of computer science and related fields. Proceedings of the 2015 ACM Conference on Innovation and Technology in CS Education. 